\title{
Kinetic study on inducibility of polygalacturonases from Aspergillus flavipes FP-500
}

\author{
Aurora Martínez-Trujillo \\ Laboratorio de Catálisis Enzimática \\ Tecnológico de Estudios Superiores de Ecatepec \\ Av. Tecnológico s/n esq. Av. Carlos Hank González \\ Ecatepec, Estado de México, CP 55210, México \\ Tel: 01550023 00. Anexo 2227 \\ E-mail: amartinezt@tese.edu.mx \\ Juan S. Aranda \\ Departmento de Bioingeniería \\ Unidad Profesional Interdisciplinaria de Biotecnología \\ Instituto Politécnico Nacional \\ Av. Acueducto s/n, Col. La Laguna Ticoman \\ D.F.CP 07340, México \\ Tel: 01572960 00. Anexo 56338 \\ E-mail: jaranda@upibi.ipn.mx

\section{Guillermo Aguilar-Osorio*} \\ Departamento de Alimentos y Biotecnología \\ Facultad de Química \\ Universidad Nacional Autónoma de México \\ Ciudad Universitaria, Conj. E, Química \\ CP 04510, D.F., México \\ Tel: 015556225305 \\ E-mail: gao@servidor.unam.mx
}

\begin{abstract}
Financial support: This work was financially supported by the National Council for Science and Technology (Mexico), the Technologic Institute for Higher Studies of Ecatepec (México), the Research Office of the National Polytechnique Institute (Mexico), and the National University of Mexico, DGAPA projects IN207603 and IN219604.
\end{abstract}

Keywords: constitutive enzymes, inducible enzymes, initial $\mathrm{pH}$, kinetic modeling, pectinases.

The aim of this work was to describe growth dynamics, substrate depletion and polygalacturonases production by Aspergillus flavipes FP-500 in batch cultures by means of unstructured models. The microorganism was cultivated on several mono- di- and poly- saccharides, and then the culture development modeled with Monod and Leudeking-Piret equations. The kinetic parameters related to the models $\left(\mu_{\max }, \gamma_{x / s}, \alpha\right.$ and $\left.\beta\right)$ were obtained by minimizing the quadratic residuals function with a simplex algorithm. An accurate description of experimental data was attained with the proposed models. Besides, modeling provided significant kinetic information on microbial degradation of complex substrates, such as the correlation between specific growth rate $\mu_{\max }$ and production yield $\alpha$, suggesting that A. flavipes FP-500 polygalacturonases are actually constitutive, but also that there is a certain degree of induciblility in these enzymatic activities.

Pectin is a complex polysaccharide found in middle lamellae of plant cell wall. It represents the first plant barrier during microbial attack which involves the action of several enzymes (de Vries and Visser, 2001). Fungi of the genus Aspergillus are among the microbial species that can degrade pectin, so producing a number of pectinases (Texeira et al. 2000). The importance of pectin-degrading enzymes lies mainly in their actual and potential uses in a number of industries, like in food processing, textile industry, paper and pulp industry, pectic wastewater treatment and animal feed, among others (Jayani et al. 2005; Niture, 2008). In addition, the understanding of the regulation process of the production of polygalacturonases will contribute to get insights in the molecular dialogue between the host and the pathogen, during microbial invasion of plant cell wall (Esquerré-Tugayé et al. 2000; Lang and Dörnenburg, 2000).

Although the specific signal molecule that triggers pectinases synthesis remains unknown, the general accepted idea is that fungal cells produce a low level of constitutive pectinolytic enzymes, which release a few molecules of mono or oligosaccharides from a polymer in

*Corresponding author 

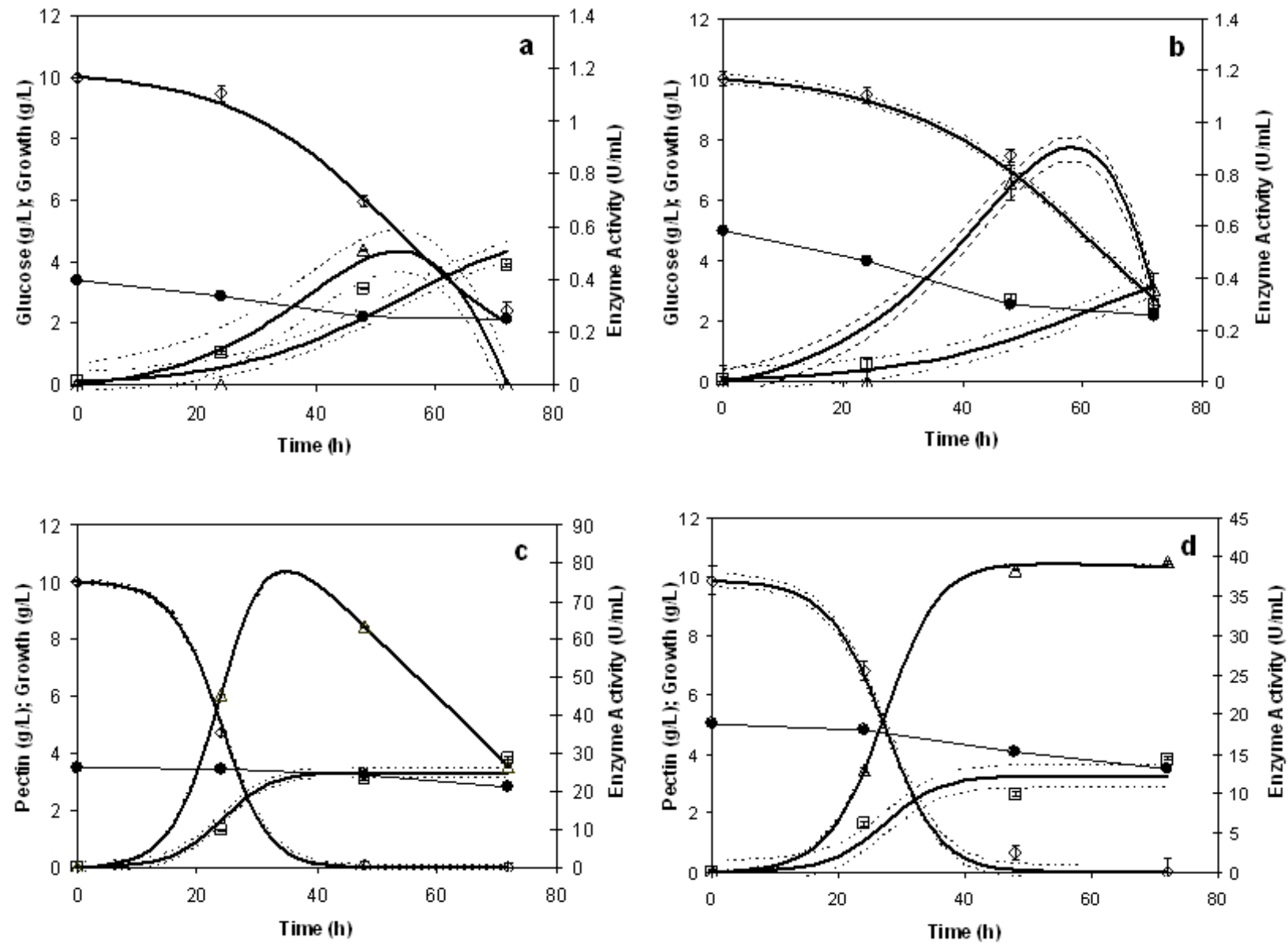

Figure 1. Fitting (continuous line) of the experimental data to a kinetic model for substrate depletion $(\diamond)$, growth $(\square)$ and polygalacturonases production $(\triangle$ ), at initial pH of 3.5 (a and c) and 5.0 (b and d) with glucose (a and b) and pectin (c and d) as carbon source. Dotted lines represent confidence intervals for the model estimations of $S, x$ and $p$. Solid markers $(-)$ are $\mathrm{pH}$ evolution in the culture.

plant structure. These small molecules are transported into the microorganism and start a massive expression of the degrading pectinases (Mach and Zeilinger, 2003). This would mean that several pectinolytic activities are induced by a number of substrates (Prade et al. 1999). Pectinases production is regulated in different fungal species, depending on the carbon source (Crotti et al. 1998; Wubben et al. 2000; Olsson et al. 2003) and the $\mathrm{pH}$ of the medium (de Vries and Visser, 2001; Peñalva and Arst, 2002).

The mathematical modeling of microbial growth and process performance has led to improved design and operation of mycelial fermentations and has improved the ability of scientists to translate laboratory observations into commercial practice. Unstructured modeling represents a particular and useful application of growth mathematical analysis that could provide some important hints on constitutiveness and inducibility of metabolites production, such as some enzymatic activities, on a kinetic, quantitative basis.
In this context, the present work aimed at describing the dynamics of fungal growth, substrate depletion and polygalacturonases production in batch cultures under different conditions of carbon source and initial $\mathrm{pH}$ of the culture, using the Monod and Leudeking-Piret unstructured models (Thilakavathi et al. 2007). After obtaining the kinetic parameters, their numerical values were correlated in order to point out the constitutive or inducible nature of the produced polygalacturonases.

\section{MATERIALS AND METHODS}

\section{Microorganism}

Aspergillus flavipes FP-500, was isolated in Mexico from rotten tomatoes. The strain was maintained at $4^{\circ} \mathrm{C}$ on PDA agar plates.

The strain was identified by conventional methods considering its morphological characteristics growing on 
different media and by microscopic examination. A comparison with type strains was done resulting in the identification of the strain as member of flavipes species.

\section{Media composition}

A. flavipes FP-500 was grown on basal medium, containing $\left(\mathrm{g} \mathrm{L}^{-1}\right): \mathrm{K}_{2} \mathrm{HPO}_{4}, 2 ; \mathrm{KH}_{2} \mathrm{PO}_{4}, 2$; and $\left(\mathrm{NH}_{4}\right)_{2} \mathrm{SO}_{4}$, 5. The medium was sterilized by autoclaving at $121^{\circ} \mathrm{C}$ for $20 \mathrm{~min}$. The initial $\mathrm{pH}$ of the medium was adjusted with $2 \mathrm{M} \mathrm{NaOH}$ or $\mathrm{H}_{2} \mathrm{SO}_{4}$. To this basal salt solution, a suitable carbon source was added to attain a final concentration of $10 \mathrm{~g} \mathrm{~L}^{-1}$.

\section{Inoculum}

Spores were collected from 3-day-old agar slants with Saline-Tween solution ( $\mathrm{NaCl}, 0.9 \%$ and Tween $80,0.01 \%$ ). A final concentration of $1 \times 10^{6}$ spores $/ \mathrm{mL}$ was obtained by adjusting with sterile water. Monosaccharide based media (see below) were supplemented with $0.1 \%(\mathrm{w} / \mathrm{v})$ of yeast extract.

\section{Production of enzymes under different carbon sources and initial pH}

In order to evaluate the effect of carbon source and initial $\mathrm{pH}$ on growth and enzyme production, A. flavipes FP-500 was grown on basal medium supplemented with different carbon sources: pectin and polygalacturonic acid, as complex polysaccharides; galacturonic acid, arabinose, rhamnose and xylose, as the main monosaccharide constituents of pectin; glycerol as a simple substrate not related to pectin structure; lactose and glucose, this latter considered a universal catabolic repressor. Also, three initial $\mathrm{pH}$ values of the culture media were established (3.5, 4.2 and 5.0), in order to evaluate microbial growth and polygalacturonases production under these different conditions. Cultures were carried out in $100 \mathrm{~mL}$ of medium, and were incubated at $37^{\circ} \mathrm{C}$ in a reciprocant shaker at $200 \mathrm{rpm}$. Samples were withdrawn every $24 \mathrm{hrs}$ until 72 hrs of culture.

\section{Analytical techniques}

Microbial biomass. Cell growth was measured by dry weight and expressed as $\mathrm{g} \mathrm{L}^{-1}$.

Polygalacturonase activity. This was measured by determination of the reducing sugars produced from $1 \%$ $(\mathrm{w} / \mathrm{v})$ pectin solution after incubation at $45^{\circ} \mathrm{C}$ for $20 \mathrm{~min}$ at $\mathrm{pH}$ 5.0. One unit of polygalacturonase activity was defined as the amount of enzyme that catalyzes the formation of 1 $\mu \mathrm{mol}$ of galaturonic acid under assay conditions (TrejoAguilar et al. 1996).

Substrate depletion. Monosaccharide substrates consumption was measured through quantification of reducing sugars using 3,5-dinitrosalicilic acid, with the corresponding sugar as the reference standard (Miller, 1959). Polymers consumption was estimated after acid hydrolysis of polysaccharides containing samples with a sulfuric acid and following color development of the phenol reagent (Dubois et al. 1956).

\section{Mathematical model}

Culture behavior in time is described with the following equations:

$\frac{d x}{d t}=\mu_{\max } \frac{S}{S+k_{S}} x$ (microbial growth)

$\frac{d S}{d t}=-\frac{\mu_{\max }}{Y_{x / s}} \frac{S}{S+k_{s}} x$ (substrate depletion)

$\frac{d p}{d t}=\alpha \mu_{\max } \frac{S}{S+k_{s}} x+\beta x$ (polygalacturonases production)

Where

$\frac{d x}{d t}$ biomass accumulation in the culture medium $\left(\mathrm{g}_{\mathrm{b}} \mathrm{L}^{-1}\right.$ $\left.\mathrm{h}^{-1}\right)$

$\frac{d S}{d t}$ substrate depletion in the culture medium $\left(\mathrm{g}_{\mathrm{s}} \mathrm{L}^{-1} \mathrm{~h}^{-1}\right)$

$\frac{d p}{d t} \quad$ exopectinases accumulation in the culture medium $\left(\mathrm{U} \mathrm{L}^{-1} \mathrm{~h}^{-1}\right)$

$\mu_{\max } \quad$ maximal specific growth rate $\left(\mathrm{h}^{-1}\right)$

S substrate concentration $\left(\mathrm{g}_{\mathrm{s}} \mathrm{L}^{-1}\right)$

$k_{s} \quad$ Monod saturation constant $\left(\mathrm{g}_{\mathrm{s}} \mathrm{L}^{-1}\right)$

$x \quad$ biomass concentration $\left(\mathrm{g}_{\mathrm{b}} \mathrm{L}^{-1}\right)$

$Y_{x / s} \quad$ biomass on substrate yield coefficient $\left(\mathrm{g}_{\mathrm{b}} \mathrm{g}_{\mathrm{s}}^{-1}\right)$

$\alpha \quad$ growth-associated coefficient for pectinases production $\left(\mathrm{U} \mathrm{g}_{\mathrm{b}}{ }^{-1}\right)$

$\beta \quad$ growth-independent coefficient for pectinases production $\left(\mathrm{U} \mathrm{g}_{\mathrm{b}}^{-1} \mathrm{~h}^{-1}\right)$

Monod constants $\mu_{\max }$ and $k_{s}$ are not simultaneously identifiable in batch process (Nihtila and Virkkunen, 1977; Chouakri et al. 1994), so the maximal specific growth rate is the only useful obtained parameter.

Kinetic parameters in the Leudeking-Piret model, $\alpha$ and $\beta$, indicate the relation between growth and pectinases production in a fungus culture. The parameter $\alpha$ expresses 
the enzyme production associated with microorganism growth, in a way that production is considered growthassociated whenever $\alpha \neq 0$. Since pectinases production is needed for the assimilation of complex substrates in order the miocroorganism to grow, parameter $\alpha$ is the more meaninful factor in our modeling approach. Besides, the estimation of $\beta$ resulted in a nil value for any Aspegillus flavipes culture. The former considerantions lead to specify the vector parameter $P$ as:

$\mathrm{P}=\left[\mu_{\max } \gamma_{x / s} \alpha\right]$ and the initial conditions to model equations $\left(x_{0}, S_{0}\right.$ and $\left.p_{0}\right)$ are the experimental concentrations at process time $t=0$.

\section{Parameters estimation}

The growth yield $\left(Y_{x / S}\right)$ and the identifiable parameters for Monod $\left(\mu_{\max }\right)$ and Luedeking-Piret $(\alpha)$ models were obtained as reported in a previous work (Aranda-Barradas et al. 2000), with the following residuals function $F$ as the minimizing criterium:

$$
\begin{aligned}
& F\left(\left[\begin{array}{llll}
\mu_{\max } & Y_{x / s} & \alpha & \beta
\end{array}\right]\right)=F(\boldsymbol{P}) \\
& F(\boldsymbol{P})=\sum_{i=1}^{n}\left[x_{i}^{\text {exp }}-x_{i}^{\bmod }(\boldsymbol{P})\right]^{2}+\sum_{i=1}^{n}\left[s_{i}^{\exp }-s_{i}^{\bmod }(\boldsymbol{P})\right]^{2}+\sum_{i=1}^{n}\left[p_{i}^{\exp }-p_{i}^{\bmod }(\boldsymbol{P})\right]^{2}
\end{aligned}
$$

Where superscripts exp and mod indicate experimental data and model results, respectively. The differences between experimental and theoretical values were calculated for the $n$ sample points $(n=12)$. The estimated kinetic parameters $P_{e s t}$ are those that satisfy the condition

$F\left(P_{e s t}\right)=\min$

Meaning that the estimated parameters are chosen in order to produce the minimum residual errors between the model theoretical values and the experimental data. The search of the minimum was carried out with a Nelder-Mead simplex method, given an arbitrary initial vector $P_{0}$ to start up the algorithm.

The model can be coupled to estimated parameters $P_{\text {est }}$ in order to create synthetic data sets, by adding white noise to numerical results on $x, S$ and $p$ from the model. Each synthetic data set produces a new vector of equivalent estimated parameters. Therefore, calculating a number of equivalent parameters allows the estimation of the mean and the standard deviation for every kinetic parameter (Table 1).

\section{Variance estimations in the model}

Variance associated to parameters. Confidence intervals of the best estimated parameters are given by

$$
\Delta P_{i}= \pm t_{0.975} \frac{\sigma_{i}}{\sqrt{m N-q}}
$$

Where

$\sigma \quad$ standard deviation for each kinetic parameter $(i=$ $\mu_{\max }, \gamma_{x / s}$ or $\alpha$ ), obtained from synthetic data

$m \quad$ experimental determinations made in $N$ samples

$N \quad$ samples obtained from each culture

$q \quad$ number of estimated parameters

$t_{0.975}$ Student's factor for a confidence level $\alpha_{\mathrm{t}}=0.975$

Estimated variance to $x, S$ and $p$. Variance of experimental data obtained after estimation of biomass $(x)$, substrate $(S)$ and exopectinases $(p)$ was estimated by

$V(u)=\frac{1}{m N-q} \sum\left(u_{\exp }-u_{\bmod }\right)^{2}$

where

$u \quad x, S$ or $p$

\section{RESULTS}

\section{Modeling of growth and pectinases production}

Kinetic parameters $\left(\mu_{\max }, \gamma_{x / s}, \alpha\right)$ estimated by Nelder-Mead simplex algorithm (Table 1) showed to be accurate enough to build a reliable model that describes the kinetics of Aspergillus flavipes FP-500 on several carbon sources, as it can be seen from the model fitting in Figure 1. A good fit to experimental data was reached with this mathematical treatment.

\section{Kinetic parameters as a function of $\mathrm{pH}$ and substrate}

Kinetic parameters for the mathematical model were determined in each experimental condition described before. Monod-type growth on substrates such as xylose, glycerol and polygalacturonic acid resulted in maximal specific growth rates around $0.03 \mathrm{~h}^{-1}$, while on galacturonic acid $\mu_{\max } \approx 0.07 \mathrm{~h}^{-1}$ and on lactose $\mu_{\max }$ was about $0.25 \mathrm{~h}^{-1}$. With all the forementioned substrates the maximal specific growth rate was approximately constant regardless the initial $\mathrm{pH}$ in the culture. Thus, for these substrates, estimated $\mu_{\max }$ values seem to indicate dependence of growth on the carbon source, but not on the initial $\mathrm{pH}$ of the culture. However, estimated $\mu_{\max }$ for other group of substrates (glucose, rhamnose, pectin) was strongly affected by the initial $\mathrm{pH}$. On the one hand, experiments with rhamnose as a carbon source showed increasing $\mu_{\max }$ values as the initial $\mathrm{pH}$ was rised from 3.5 to 5.0. Growth on glucose and pectin presented a significative drop of the specific growth rate $\mu_{\max }$ when the initial $\mathrm{pH}$ in the culture was increased. 
Concerning polygalacturonases production represented by the Leudeking-Piret model, estimated $\beta$ values were equal to zero for all the substrates and initial $\mathrm{pH}$ tested. In contrast, $\alpha$ parameter estimations showed a dependence on both the substrates and the initial $\mathrm{pH}$. The lowest $\alpha$ value was obtained for glycerol $(0.004 \mathrm{U} / \mathrm{g}, \mathrm{pH}=3.5)$, meanwhile high values were obtained for rhamnose $(25.6 \mathrm{U} / \mathrm{g}, \mathrm{pH}=$ 4.2), galacturonic acid (37.89 U/g, $\mathrm{pH}=3.5)$, polygalacturonic acid $(27.88 \mathrm{U} / \mathrm{g}, \mathrm{pH}=5.0)$ and pectin $(30.78 \mathrm{U} / \mathrm{g}, \mathrm{pH}=3.5)$. Values obtained for pectin and galacturonic acid were exceptionally high when compared to other substrates in media with initial $\mathrm{pH}$ of 3.5 . Similarily, for glycerol, the product yield $\alpha$ is relatively high $(15.71 \mathrm{U} / \mathrm{g}$ for $\mathrm{pH}=4.2$ and $16.17 \mathrm{U} / \mathrm{g}$ for $\mathrm{pH}=5.0)$ although this substrate is not a structural component of pectin.

\section{Polygalacturonases inducibility from kinetic \\ constitutiveness}

and

\section{Parameters}

After comparing kinetic parameters for different carbon sources and initial $\mathrm{pH}$ values, some interesting remarks can be established concerning the relationship between estimated $\mu_{\max }$ and $\alpha$ (Figure 2). Three major trends were observed:

i) For glucose, plotting $\mu_{\max } v s . \alpha$ it could be observed that the estimated $\mu_{\max }$ values strongly depended on the $\mathrm{pH}$ of the medium (Figure 2a). While $\alpha$ value at $\mathrm{pH} 3.5$ and 4.2 was similar at 5.0 a higher value was obtained. However, this latter value was relatively low as compared with other substrates.

ii) For substrates as lactose, galacturonic acid or polygalacturonic acid, estimated $\mu_{\max }$ was the same on the three initial $\mathrm{pH}$ tested. However, different $\alpha$ values were obtained, depending on the initial $\mathrm{pH}$ used for each medium. A graphical representation of $\mu_{\max }-\alpha$ parameters shows a linear, nearly vertical, relationship (Figure $2 b$ ).

iii) With pectin as the carbon source, there is a positive proportional relationship between $\mu_{\max }$ and $\alpha$ (Figure 2c).

These experimental results could be interpreted in terms of constitutiveness or inducibility of pectinases as a function either of initial $\mathrm{pH}$ in the culture media or of the carbon source.

Table 1. Kinetic parameters for A. flavipes FP-500 on several carbon sources and different starting $\mathrm{pH}$.

\begin{tabular}{|c|c|c|c|c|c|c|c|c|c|}
\hline Kinetic parameter & \multicolumn{3}{|c|}{$\begin{array}{l}\mu_{\max } \\
\left(\mathbf{h}^{-1}\right)\end{array}$} & \multicolumn{3}{|c|}{$\begin{array}{c}Y_{X / S} \\
\text { (g of biomass/g of substrate) }\end{array}$} & \multicolumn{3}{|c|}{$\begin{array}{c}\alpha \\
\text { (U/g of biomass) }\end{array}$} \\
\hline \multirow{2}{*}{ Carbon source } & \multicolumn{3}{|c|}{$p H$} & \multicolumn{3}{|c|}{$p H$} & \multicolumn{3}{|c|}{$\mathrm{pH}$} \\
\hline & 3.5 & 4.2 & 5.0 & 3.5 & 4.2 & 5.0 & 3.5 & 4.2 & 5.0 \\
\hline Xylose & $\begin{array}{c}0.029 \pm \\
0.008\end{array}$ & $\begin{array}{l}0.029 \pm \\
0.0026\end{array}$ & $\begin{array}{c}0.026 \pm \\
0.002\end{array}$ & $\begin{array}{l}0.411 \pm \\
0.05\end{array}$ & $\begin{array}{l}0.257 \pm \\
0.0071\end{array}$ & $\begin{array}{l}0.46 \pm \\
0.024\end{array}$ & $\begin{array}{c}0.013 \pm \\
0.003\end{array}$ & $\begin{array}{c}0.73 \pm \\
1.58\end{array}$ & $\begin{array}{l}0.84 \pm \\
0.087\end{array}$ \\
\hline Rhamnose & $0.04 \pm 0.01$ & $\begin{array}{l}0.098 \pm \\
0.006\end{array}$ & $\begin{array}{l}0.104 \pm \\
0.006\end{array}$ & $\begin{array}{c}0.44 \pm \\
0.03\end{array}$ & $0.31 \pm 0.03$ & $\begin{array}{l}0.39 \pm \\
0.017\end{array}$ & $1.30 \pm 0.2$ & $\begin{array}{c}25.6 \pm \\
1.43\end{array}$ & $\begin{array}{c}4.21 \pm \\
0.06\end{array}$ \\
\hline Arabinose & $\begin{array}{l}0.15 \pm \\
0.021\end{array}$ & $\begin{array}{l}0.05 \pm \\
0.0007\end{array}$ & $0.12 \pm 0.03$ & $\begin{array}{l}0.36 \pm \\
0.06\end{array}$ & $0.44 \pm 0.02$ & $\begin{array}{c}0.37 \pm \\
0.03\end{array}$ & $3.1 \pm 0.96$ & $\begin{array}{c}5.18 \pm \\
0.68\end{array}$ & $8.3 \pm 0.52$ \\
\hline Galacturonic acid & $\begin{array}{c}0.069 \pm \\
0.008\end{array}$ & $0.064 \pm 0.01$ & $\begin{array}{l}0.079 \pm \\
0.005\end{array}$ & $\begin{array}{l}0.44 \pm \\
0.05\end{array}$ & $0.39 \pm 0.04$ & $\begin{array}{c}0.35 \pm \\
0.03\end{array}$ & $37.89 \pm 2.9$ & $\begin{array}{c}4.14 \pm \\
0.98\end{array}$ & $\begin{array}{c}14.53 \pm \\
2.5\end{array}$ \\
\hline $\begin{array}{l}\text { Polygalacturonic } \\
\text { acid }\end{array}$ & $\begin{array}{l}0.034 \pm \\
0.005\end{array}$ & $\begin{array}{l}0.032 \pm \\
0.0021\end{array}$ & $\begin{array}{l}0.027 \pm \\
0.0022\end{array}$ & $\begin{array}{l}0.30 \pm \\
0.014\end{array}$ & $0.34 \pm 0.03$ & $\begin{array}{c}0.26 \pm \\
0.09\end{array}$ & $11.97 \pm 1.53$ & $\begin{array}{c}19.99 \pm \\
1.67\end{array}$ & $\begin{array}{l}27.88 \pm \\
2.7\end{array}$ \\
\hline Pectin & $0.76 \pm 0.06$ & $0.55 \pm 0.06$ & $\begin{array}{l}0.039 \pm \\
0.007\end{array}$ & $\begin{array}{l}0.34 \pm \\
0.007\end{array}$ & $0.34 \pm 0.03$ & $\begin{array}{c}0.68 \pm \\
0.09\end{array}$ & $30.78 \pm 0.95$ & $\begin{array}{l}12.13 \pm \\
0.33\end{array}$ & $6.27 \pm 2.2$ \\
\hline Glucose & $0.17 \pm 0.03$ & $0.07 \pm 0.01$ & $0.08 \pm 0.04$ & $\begin{array}{c}0.49 \pm \\
0.04\end{array}$ & $0.52 \pm 0.01$ & $\begin{array}{l}0.41 \pm \\
0.036\end{array}$ & $0.32 \pm 0.11$ & $\begin{array}{l}0.12 \pm \\
0.05\end{array}$ & $\begin{array}{l}1.65 \pm \\
0.15\end{array}$ \\
\hline Glycerol & $\begin{array}{l}0.035 \pm \\
0.003\end{array}$ & $\begin{array}{l}0.027 \pm \\
0.007\end{array}$ & $\begin{array}{l}0.026 \pm \\
0.005\end{array}$ & $\begin{array}{c}0.48 \pm \\
0.02\end{array}$ & $0.26 \pm 0.02$ & $\begin{array}{c}0.26 \pm \\
0.06\end{array}$ & $\begin{array}{l}0.004 \pm \\
0.0024\end{array}$ & $\begin{array}{c}15.71 \pm \\
2.45\end{array}$ & $\begin{array}{c}16.17 \pm \\
1.21\end{array}$ \\
\hline Lactose & $\begin{array}{l}0.24 \pm \\
0.008\end{array}$ & $0.25 \pm 0.04$ & $0.27 \pm 0.03$ & $\begin{array}{c}0.31 \pm \\
0.04\end{array}$ & $0.95 \pm 0.17$ & $\begin{array}{c}0.98 \pm \\
0.13\end{array}$ & $9.91 \pm 1.97$ & $\begin{array}{c}8.45 \pm \\
2.12\end{array}$ & $\begin{array}{c}3.67 \pm \\
1.57\end{array}$ \\
\hline
\end{tabular}



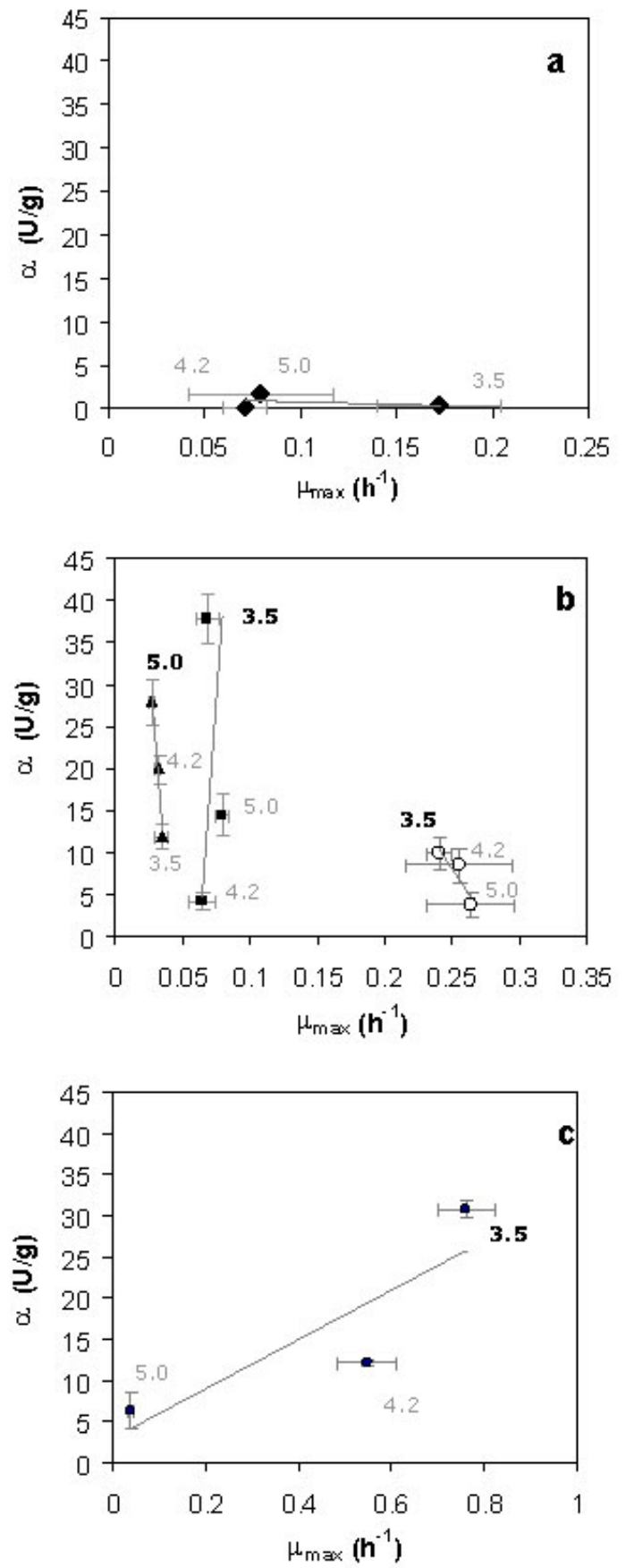

Figure 2. Relationships $\mu_{\max }-\alpha$, at different initial $\mathrm{pH}$, for (a) glucose $(\mathbf{)})$, (b) galacturonic acid, $(\mathbf{a})$; polygalacturonic acid $(\boldsymbol{\Delta})$, and lactose, $(\mathrm{O})$ and $(\mathrm{c})$ pectin $(\boldsymbol{\theta})$. Numbers asociated to markers indicate the initial $\mathrm{pH}$ in the culture media.

\section{DISCUSSION}

It can be clearly seen on Figure 1 that although final biomass for growth on glucose and pectin is similar, glucose is not depleted in the process time, contrary to pectin which is exhausted after $48 \mathrm{hrs}$. These findings suggest that $A$. flavipes FP-500 is better adapted to complex polysaccharides than to monosaccharides, since kinetics of growth is faster on the former substrates.

It should be observed that $\mu_{\max }$ varied in different carbon sources, with a clear trend to be higher for lactose and pectin than for monosacharide susbtrates. It is interesting to notice that this strain was able to grow on lactose as a sole carbon source and this is not usual. Other filamentous fungi showed a low growth rate on this substrate (Pakula et al. 2005), even when this carbon source has been reported as the inducer of cellulases in Hypocrea jecorina (anamorph of Trichoderma reesei), (Seiboth et al. 2004). The growth on lactose is related to the presence of $\beta$-galactosidase activity, a key enzyme for lactose utilization by this fungus. Considering that lactose does not occur in the natural environment of fungi, it has been proposed that the function of this $\beta$-galactosidase is the hydrolysis of terminal nonreducing $\beta$-D-galactose residues in plant cell wall components including hemicelluloses or pectins (Seiboth et al. 2007). Furthermore, in Aspergillus there is not a clear picture about lactose utilization; while $A$. nidulans is able to grow on lactose and galactose, $A$. niger does not (Seiboth et al. 2007). As it can be seen from our results, A. flavipes grows on lactose and is able to produce $\alpha$ - and $\beta$ galactosidase. So, it is probable that A. flavipes FP-500 is using a similar strategy to $A$. nidulans that allow the growth on lactose. Nevertheless, it would be necessary to develop additional experiments for demonstrating this hypothesis.

The highest $\mu_{\max }$ values were reached with data from a pectin culture, so pectin allows a good microbial biomass production in this strain. Besides, this behavior could explain the elevated polygalacturonases production of the fungus when it grew on pectin as carbon source. A. flavipes FP-500 is a good pectinases producer, whose pectinases production is better than other Aspergillus strains, such as those reported for A. niger F-1119, which produced barely $10.8 \mathrm{U} / \mathrm{ml}$ and $2.1 \mathrm{~g} / \mathrm{L}$ of biomass on citrus pectin (Shubakov and Elkina, 2002).

The $\alpha$ parameter involved in Leudeking-Piret model expresses the enzyme production associated with the growth of the microorganism. Moreover, analysis of $\mu_{\max }$ $\alpha$ plots can give some insight about constitutiveness, if $\alpha$ remains constant eventhough changes in $\mu_{\max }$ are presented; or inducibility, if $\alpha$ increases regardless the behavior of $\mu_{\max }$.

For growth on glucose (Figure 2a), no matter what initial $\mathrm{pH}$ was adjusted in the culture, low values for $\alpha$ were obtained. The numerical values were not higher than 1.65 $\mathrm{U} / \mathrm{g}$ what is considered relatively low, and might be reflecting a basal enzyme activity. Taking into account that glucose is not a constituent of pectin structure, the behavior observed in this $\mu_{\max }-\alpha$ relationship suggests that there is a constitutive part of polygalacturonases produced by $A$. 
flavipes FP-500, which is expressed under any $\mathrm{pH}$ condition.

With other substrates unrelated to pectin structure (glycerol and lactose) $\alpha$ ranged from 0.004 to $\sim 15 \mathrm{U} / \mathrm{g}$. However, $\alpha$ raised up to $25 \mathrm{U} / \mathrm{g}$ or more for cultures developed on carbon sources related to pectin. Among them, the highest was attained on galacturonic acid, and it was comparable in magnitude to those observed for polygalacturonic acid and pectin. This seems to indicate a certain substrateinducibility degree in the enzymatic production.

When a graphical analysis between $\mu_{\max }$ and $\alpha$ was performed for pectin-related substrates, different behaviors were observed. On galacturonic acid, the fungus had the same maximal specific growth rate $\left(\sim 0.07 \mathrm{~h}^{-1}\right)$ but different $\alpha$ values for every initial $\mathrm{pH}$ tested (Figure 2b). This suggests that on galacturonic acid there is an induction in this strain of polygalacturonase activity depending on initial $\mathrm{pH}$, as it has been reported for other Aspergillus species (de Vries et al. 2002). On polygalacturonic acid (Figure 2b) it was clear that initial $\mathrm{pH}$ of the medium also conditioned the polygalacturonases activity. It seems that for almost all the substrates, the initial $\mathrm{pH}$ of 3.5 increases polygalacturonases activity. Thus, initial $\mathrm{pH}$ conditions regulate pectinases activity.

Some similar conclusions have been reached in induction and repression research on cellulases by $A$. niger (Hanif et al. 2004). However, although our results on kinetic modeling certainly give some insight on polygalacturonases production, constitutiveness and inducibility, there is still room for other confirmatory experiments.

\section{CONCLUDING REMARKS}

Aspergillus flavipes FP-500 is a pectinases producer strain. Our results have shown that polygalacturonases production is strongly influenced by the available carbon source, and that enzyme activity is regulated by the initial $\mathrm{pH}$ in the culture medium. The main contribution lies in the kinetic characterization of polygalacturonases production by the strain, that allowed to stress to some extent the constitutiveness and inducibility of those enzymes:

i) Growth on monomeric substrates unrelated to pectine (glucose, gycerol) resulted in a low polygalacturonases production, considered a basal constitutive enzyme activity, that can be modified by means of a change in the initial $\mathrm{pH}$ of the culture medium.

ii) Culture media containing monomeric substrates related to pectin (xylose, rhamnose, arabinose) produced in general a low polygalacturonases yield $(\alpha)$, eventhough some important increases in enzymatic activity are attained by establishing the appropiate initial $\mathrm{pH}$ (3.5 for galacturonic acid and 4.2 for rhamnose) in the culture medium.

iii) Complex substrates such as pectin or polygalacturonic acid induced important polygalacturonase production that was significantly increased at low $\mathrm{pH}$ (3.5) for pectin, or at a slightly higher $\mathrm{pH}$ (5.0) for polygalacturonic acid.

Even though kinetic parameters are not definitive evidence of enzyme induction, an indirect inference from $\mu_{\max }-\alpha$ relationship would indicate the conditions for an increase of enzymatic activity, mainly due to substrate induction.

\section{ACKNOWLEDGMENTS}

The authors acknowledge Dr. Edgar Salgado for the critical reading of the manuscript.

\section{REFERENCES}

ARANDA-BARRADAS, Juan S.; DELIA, Marie Line and RIBA, Jean-Pierre. Kinetic study and modeling of the xylitol production using Candida parapsilosis in oxygenlimited culture conditions. Bioprocess and Biosystems Engineering, March 2000, vol. 22, no. 3, p. 219-225.

CHOUAKRI, N.; FONTEIX, C.; MARC, I. and CORRIOU, J.P. Parameter estimation of a Monod-type model. Part I: Theoretical identifiability and sensitivity analysis. Biotechnology Techniques, October 1994, vol. 8, no. 10 , p. 683-688.

CROTTI, Luciana B.; TERENZI, Héctor F.; JORGE Joao A. and POLIZELI, María de Lourdes. Regulation of pectic enzymes from the exo-1 mutant strain of Neurospora crassa: effects of glucose, galactose and galacturonic acid. Journal of Basic Microbiology, July 1998, vol. 38, no. 3, p. 181-188.

DE VRIES, Ronald P. and VISSER, Jap. Aspergillus enzymes involved in degradation of plant cell wall polysaccharides. Microbiology and Molecular Biology Reviews, December 2001, vol. 65, no. 4, p. 497-522.

DE VRIES, Ronald P.; JANSEN, Jenny; AGUILAR, Guillermo; PARENICOVA, Lucile; JOOSTEN, Vivi; WÜLFERT, Florian; BENEN, Jacques A.E. and VISSER, Jaap. Expression profiling of pectinolytic genes from Aspergillus niger. FEBS Letters, September 2002, vol. 530, no.1-3, p. 41-47.

DUBOIS, M.; GILLES, K.A.; HAMILTON, J.K.; REBERS, P.A. and SMITH, F. Colorimetric method for determination of sugars and related substances. Analytical Chemistry, March 1956, vol. 28, no. 3, p. 350-356.

ESQUERRÉ-TUGAYÉ, Marie-Thérese; BOUDART, Georges and DUMAS, Bernard. Cell wall degrading enzymes, inhibitory proteins, and oligo-saccharides participate in the molecular dialogue between plants and pathogens. Plant Physiology and Biochemistry, January 2000, vol. 38, no. 1-2, p. 157-63.

HANIF, A.; YASMEEN, A. and RAJOKA, M.I. Induction, production, repression, and de-repression of exoglucanase 
synthesis in Aspergillus niger. Bioresource Technology, September 2004, vol. 94, no. 3, p. 311-319.

JAYANI, Ranveer Singh; SAXENA, Shivalika and GUPTA, Reena. Microbial pectinolytic enzymes: A review. Process Biochemistry, September 2005, vol. 40, no. 9, p. 2931-2944.

LANG, C. and DÖRNENBURG, H. Perspectives in the biological function and the technological application of polygalacturonases. Applied Microbiology and Biotechnology, April 2000, vol. 53, no. 4, p. 366-375.

MACH, R.L. and ZEILINGER, S. Regulation of gene expression in industrial fungi: Trichoderma. Applied Microbiology and Biotechnology, January 2003, vol. 60, no. 5, p. 515-522.

MILLER, G.L. Use of dinitrosalisylic acid reagent for determination of reducing sugars. Analytical Chemistry, March 1959, vol. 31, no. 3, p. 426-428.

NIHTILA, M. and VIRKKUNEN, J. Practical identifiability of growth and substrate consumption models. Biotechnology and Bioengineering, December 1977, vol. 19, p. 1831-1850.

NITURE, Suryakant. K. Comparative biochemical and structural characterizations of fungal polygalacturonases. Biologia, February 2008, vol. 63, no. 1, p. 1-19.

OLSSON, Lisbeth; CHRISTENSEN, Tove M.I.E.; HANSEN, Kim P. and PALMQVIST, Eva A. Influence of the carbon source on production of cellulases, hemicellulases and pectinases by Trichoderma reesei Rut C-30. Enzyme \& Microbial Technology, October 2003, vol. 33 , no. 5, p. 612-619.

PAKULA, Tiina M.; SALONEN, Katri; UUSITALO, Jaana and PENTTILÄ, Merja. The effect of specific growth rate on protein synthesis and secretion in the filamentous fungus Trichoderma reesei. Microbiology, January 2005, vol. 151, no. 1, p. 135-143.

PEÑALVA, Miguel A. and ARST, Herbert N. Regulation of gene expression by ambient $\mathrm{pH}$ in filamentous fungi and yeasts. Microbiology and Molecular Biology Reviews, September 2002, vol. 66, no. 3, p. 426-446.

PRADE, R.A.; ZHAN, D.; AYOUBI, P. and MORT, A.J. Pectins, pectinases and plant-microbe interactions. Biotechnology and Genetic Engineering Reviews, 1999, vol. 16, p. 361-391.

SEIBOTH, Bernhard; HARTL, Lukas; PAIL, Manuela; FEKETE, Erzsébet; KARAFFA, Levente and KUBICEK, Christian P. The galactokinase of Hypocrea jecorina is essential for cellulase induction by lactose but dispensable for growth on D-galactose. Molecular Microbiology, February 2004, vol. 51, no. 4, p. 1015-1025.
SEIBOTH, Bernhard; PAKDAMAN, Babak S.; HARTL, Lukas and KUBICEK, Christian P. Lactose metabolism in filamentous fungi: how to deal with an unknown substrate. Fungal Biology Reviews, February 2007, vol. 21, no. 1, p. 42-48.

SHUBAKOV, Anatoly A. and ELKINA, Elena A. Production of polygalacturonases by filamentous fungi Aspergillus niger ACMF-1119 and Penicillium dierckxii ACIMF-152. Chemistry and Computational Simulation, 2002 , vol. 2 , no. 7 , p. $65-68$.

TEIXEIRA, Maria F.S.; LIMA-FILHO, José L. and DURÁN, Nelson. Carbon sources effect on pectinase production from Aspergillus japonicus 586. Brazilian Journal of Microbiology, October/December, 2000, vol. 31, no. 4, p. 286-290.

THILAKAVATHI, Mani; BASAK, Tanmay and PANDA, Taprobata. Modeling of enzyme production kinetics. Applied Microbiology and Biotechnology, January 2007, vol. 73, no. 5, p. 991-1007.

TREJO-AGUILAR, Blanca; VISSER, Jaap and AGUILAR-OSORIO, Guillermo. Pectinase secretion by Aspergillus FP-180 and Aspergillus niger N402 growing under stress induced by the $\mathrm{pH}$ of culture medium. In: VISSER, J. and VORAGEN, A.G.J. eds. Pectins and Pectinases: Proceedings of an International Symposium, (December $3^{\text {rd }}$ to $7^{\text {th }}, 1995$, Wageningen, The Netherland). Progress in Biotechnology, 1996, vol. 14, p. 915-920.

WUBBEN, Joss P.; HAVE, ArjenTen; VAN KAN, Jan A.L. and VISSER, Jaap. Regulation of endopolygalacturonase gene expression in Botrytis cinerea by galacturonic acid, ambient $\mathrm{pH}$ and carbon catabolite repression. Current Genetics, February 2000, vol. 37, no. 2, p. $152-157$. 